\title{
Human cerebrovascular contractile receptors are upregulated via a B-Raf/MEK/ERK-sensitive signaling pathway
}

\author{
Hilda Ahnstedt ${ }^{*}$, Hans Säveland ${ }^{2}$, Ola Nilsson ${ }^{2}$, Lars Edvinsson ${ }^{1}$
}

\begin{abstract}
Background: Cerebral ischemia results in a rapid increase in contractile cerebrovascular receptors, such as the 5hydroxytryptamine type $1 \mathrm{~B}\left(5-\mathrm{HT} T_{1 \mathrm{~B}}\right)$, angiotensin II type $1\left(\mathrm{AT}_{1}\right)$, and endothelin type $\mathrm{B}\left(\mathrm{ET}_{\mathrm{B}}\right)$ receptors, in the vessel walls within the ischemic region, which further impairs local blood flow and aggravates tissue damage. This receptor upregulation occurs via activation of the mitogen-activated protein kinase pathway. We therefore hypothesized an important role for B-Raf, the first signaling molecule in the pathway. To test our hypothesis, human cerebral arteries were incubated at $37^{\circ} \mathrm{C}$ for $48 \mathrm{~h}$ in the absence or presence of a B-Raf inhibitor: SB-386023 or SB-590885. Contractile properties were evaluated in a myograph and protein expression of the individual receptors and activated phosphorylated B-Raf ( $\mathrm{p}-\mathrm{B}-$ Raf) was evaluated immunohistochemically.

Results: $5-\mathrm{HT}_{1 \mathrm{~B}}, A \mathrm{~T}_{1}$, and $\mathrm{ET}_{\mathrm{B}}$ receptor-mediated contractions were significantly reduced by application of SB590885, and to a smaller extent by SB-386023. A marked reduction in $\mathrm{AT}_{1}$ receptor immunoreactivity was observed after treatment with SB-590885. Treatment with SB-590885 and SB-386023 diminished the culture-induced increase of p-B-Raf immunoreactivity.

Conclusions: B-Raf signaling has a key function in the altered expression of vascular contractile receptors observed after organ culture. Therefore, specific targeting of B-Raf might be a novel approach to reduce tissue damage after cerebral ischemia by preventing the previously observed upregulation of contractile receptors in smooth muscle cells.
\end{abstract}

\section{Background}

Although cerebral ischemia is a leading cause of morbidity and mortality worldwide, few therapeutic advances appear to be of value in the clinic [1]. We have observed an inherent tendency of the vasculature to undergo phenotypic changes as a response to cerebral ischemia [2]. Therefore, the cerebral vessels show transcriptional upregulation of the vasoconstrictive G-protein coupled receptors (GPCRs) 5-hydroxytryptamine type $1 \mathrm{~B}\left(5-\mathrm{HT}_{1 \mathrm{~B}}\right)$, angiotensin II type $1\left(\mathrm{AT}_{1}\right)$ and endothelin type $\mathrm{B}\left(\mathrm{ET}_{\mathrm{B}}\right)$ after experimental subarachnoid hemorrhage $(\mathrm{SAH})$ or after focal ischemic stroke $[3,4]$. Identical receptor upregulation has been observed in patients that died of stroke [5]. In both types of

\footnotetext{
* Correspondence: hilda.ahnstedt@med.lu.se

'Division of Experimental Vascular Research, Department of Clinical Sciences, Lund University, Lund, Sweden

Full list of author information is available at the end of the article
}

experimental stroke, the receptor upregulation is mediated via the mitogen-activated protein kinase pathway MEK/ERK1/2 [6,7]. A similar type of receptor upregulation can be achieved experimentally by incubating isolated arteries in serum-free culture medium at $37^{\circ} \mathrm{C}$ for 12 to $48 \mathrm{~h}$ [8].

The first signaling molecule in the MEK/ERK1/2 pathway, Raf, is a serine/threonine kinase existing in three different isoforms (A-, B-, and C-Raf) with a common activator, Ras, and a single known common substrate, MEK. Even though MEK is the common substrate, experiments on Raf knock-out mice show isoform-specific functions for A-, B-, and C-Raf [9]. B-Raf is the only isoform that is strongly activated by Ras alone [10] and the most active isoform when it comes to phosphorylating MEK in vitro [11]. We therefore designed this study to examine the role of the B-Raf isoform in inducing the observed GPCR alterations seen after cerebral ischemia. 
Two previously characterized B-Raf selective inhibitors were used in this study, SB-386023 [12] and SB-590885 [13]. The inhibitors are both small ATP competitive inhibitors with high selectivity for B-Raf when tested against a panel of related protein kinases, but are different in that SB-590885 has a higher affinity for B-Raf. We show that culturing human cerebral arteries in the presence of B-Raf inhibitors strongly attenuates $5-\mathrm{HT}_{1 \mathrm{~B}}$, $\mathrm{AT}_{1}$, and $\mathrm{ET}_{\mathrm{B}}$ receptor-mediated contractions compared with arteries cultured with vehicle alone. The receptor proteins were evaluated with immunofluorescence and a marked reduction in $\mathrm{AT}_{1}$ receptor immunofluorescence was observed after treatment with SB-590885. Additionally, the observed increase in phosphorylated B-Raf ( $p$ B-Raf) immunoreactivity after incubation was diminished after treatment with the B-Raf inhibitors.

\section{Results}

In vitro pharmacology

Initially, the vessel segments were normalized and stretched to $90 \%$ of the internal circumference that a fully relaxed vessel under a transmural pressure of 100 $\mathrm{mm} \mathrm{Hg}$ would have. The mean normalized internal circumference and standard deviation was $725 \pm 297 \mu \mathrm{m}$. K ${ }^{+}$-induced contractions did not differ significantly among the three groups; vehicle, SB-386023, and SB-590885 data confirmed that all groups responded similarly to $\mathrm{K}^{+}$, excluding the possibility that the B-Raf inhibitors had an effect on the viability of the vessels. $E_{\max }$ and $\mathrm{pEC}_{50}$ values for each group are presented in Table 1.

\section{Contractile responses to 5-carboxamidotryptamine}

$5-\mathrm{HT}_{1 \mathrm{~B}}$ receptor-mediated contraction was studied using cumulative application of 5-carboxamidotryptamine (5CT). Vessel segments treated with SB-386023 or SB-
590885 both showed attenuated contractile responses to 5-CT and gave rise to reduced $\mathrm{E}_{\max }$ values compared with vehicle-treated vessels (Figure 1A). The inhibitory effect was significant for vessels treated with SB-590885, $\mathrm{E}_{\max } 11.75 \pm 3.43 \%$ compared with $39.20 \pm 12.09 \%$ for the vehicle group $(\mathrm{P}<0.05$, Table 1$)$.

\section{Contractile responses to angiotensin II}

Application of angiotensin II (Ang II) induced a concentration-dependent contractile response at lower concentrations $\left(10^{-12}-3 \cdot 10^{-9} \mathrm{M}\right)$ and dilatation at higher concentrations $\left(10^{-8}-3 \cdot 10^{-6} \mathrm{M}\right.$, data not shown). The maximum contraction was attenuated after treatment with SB-590885 (11.56 $\pm 2.72 \%, \mathrm{P}<0.001)$ and SB386023 (26.20 $\pm 4.37 \%$, not significant) compared with $46.43 \pm 6.78 \%$ for the control vessels treated with vehicle (Figure 1B, Table 1).

\section{Contractile responses to endothelin-1}

Endothelin-1 (ET-1) gave rise to a biphasic concentration-dependent response indicating the presence of both $\mathrm{ET}_{\mathrm{A}}$ (low affinity) and $\mathrm{ET}_{\mathrm{B}}$ (high affinity) receptors in a manner previously characterized in detail [14]. The high-affinity phase corresponding to $\mathrm{ET}_{\mathrm{B}}$ receptormediated contraction was significantly decreased in the presence of SB-590885 (7.44 $\pm 2.44 \%, \mathrm{P}<0.05)$ while SB-386023 did not have a significant effect (25.60 \pm $7.40 \%$ ) compared with vehicle $36.71 \pm 12.09 \%$ (Figure $1 \mathrm{C}$, Table 1). $\mathrm{ET}_{\mathrm{A}}$ receptor-mediated contractions (lowaffinity phase) were not significantly altered by the application of either inhibitor (Figure 1C).

\section{Immunohistochemistry}

Hematoxylin-eosin staining was performed on all specimens. No morphological differences were observed in

\section{Table 1 Contractile responses to 5-CT, Ang II, and ET-1}

\begin{tabular}{|c|c|c|c|c|c|c|c|c|}
\hline & \multirow[b]{2}{*}{$\mathrm{n}$} & \multirow[b]{2}{*}{$\mathrm{K}^{+}(\mathrm{mN})$} & \multicolumn{2}{|c|}{ Sigmoidal curve } & \multicolumn{4}{|c|}{ Biphasic curve } \\
\hline & & & $\mathrm{E}_{\max }(\%)$ & $\mathrm{pEC} C_{50}$ & $E_{\max (1)}(\%)$ & $E_{\max (2)}(\%)$ & $\mathrm{pEC} \mathrm{C}_{50(1)}$ & $\mathrm{pEC} \mathrm{C}_{50(2)}$ \\
\hline \multicolumn{9}{|l|}{$5-C T$} \\
\hline Vehicle & 5 & $6.87 \pm 1.07$ & $39.20 \pm 12.09$ & $6.92 \pm 0.40$ & & & & \\
\hline SB-386023 & 6 & $7.42 \pm 1.10$ & $25.13 \pm 4.75$ & $7.28 \pm 0.31$ & & & & \\
\hline SB-590885 & 6 & $5.45 \pm 1.16$ & $11.75 \pm 3.43^{*}$ & $6.65 \pm 0.25$ & & & & \\
\hline \multicolumn{9}{|l|}{ Ang $\|$} \\
\hline Vehicle & 6 & $7.16 \pm 0.92$ & $46.43 \pm 6.78$ & $10.11 \pm 0.25$ & & & & \\
\hline SB-386023 & 7 & $7.08 \pm 0.95$ & $26.20 \pm 4.37$ & $10.15 \pm 0.23$ & & & & \\
\hline SB-590885 & 7 & $5.88 \pm 1.12$ & $11.56 \pm 2.72^{* * *}$ & $9.45 \pm 0.96$ & & & & \\
\hline \multicolumn{9}{|l|}{$E T-1$} \\
\hline Vehicle & 6 & $7.16 \pm 0.92$ & & & $36.71 \pm 12.09$ & $128.40 \pm 6.91$ & $11.74 \pm 0.20$ & $9.17 \pm 0.18$ \\
\hline SB-386023 & 7 & $7.08 \pm 0.95$ & & & $25.60 \pm 7.40$ & $132.20 \pm 8.46$ & $11.73 \pm 0.16$ & $8.96 \pm 0.20$ \\
\hline SB-590885 & 7 & $5.88 \pm 1.12$ & & & $7.44 \pm 2.44^{*}$ & $147.4 \pm 11.04$ & $11.37 \pm 0.20$ & $9.07 \pm 0.08$ \\
\hline
\end{tabular}

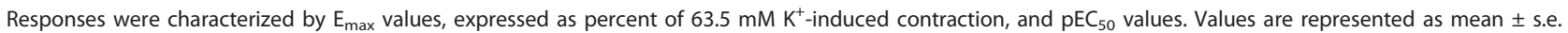
$\mathrm{m}$., with $n$ representing the number of patients. Statistical analyses were performed using the non-parametric Kruskal-Wallis test and Dunn's multiple comparison test. ${ }^{*} \mathrm{P}<0.05,{ }^{*} * \mathrm{P}<0.001$ compared with vehicle. 5-CT - 5-carboxamidotryptamine, Ang II - Angiotensin II, ET-1 - Endothelin-1. 


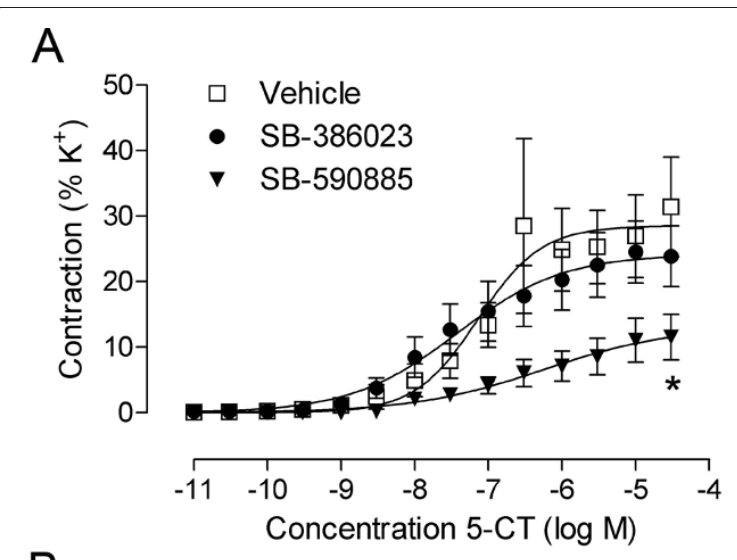

B

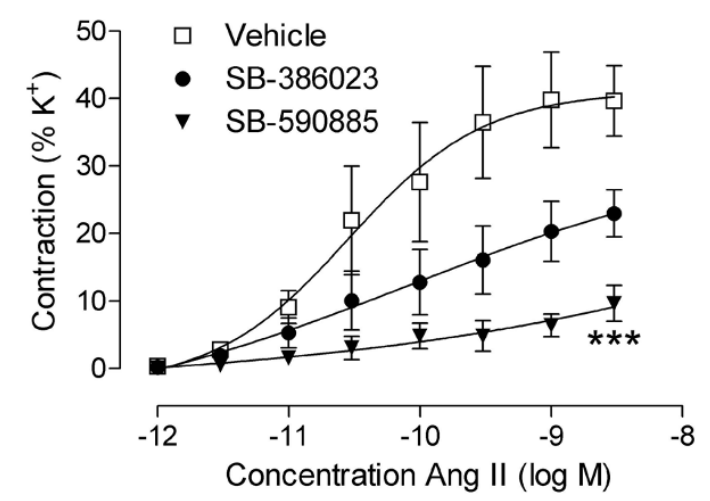

C

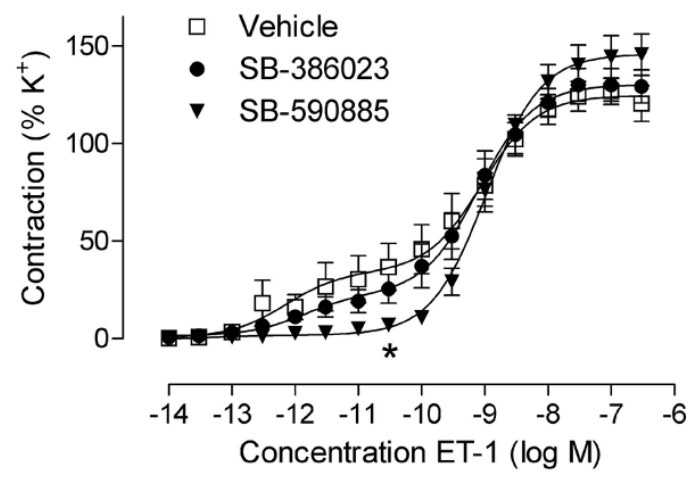

Figure 1 Contractile responses to 5-carboxamidotryptamine (5CT) (A), angiotensin II (Ang II) (B), and endothelin-1 (ET-1) (C) in human cerebral arteries. Effect of organ culture in the presence of vehicle ( $n=5$ to 6 ) and in the presence of SB-590885 ( $n=6$ to 7) and SB-386023 ( $n=6$ to 7) are illustrated. The receptor-mediated contractions are clearly reduced by SB-590885. Data are expressed as mean \pm s.e.m. ET-1 biphasic concentration-response curve: highaffinity phase refers to the endothelin type $B\left(E T_{B}\right)$ receptormediated contraction; low-affinity phase refers to the endothelin type $A\left(E T_{A}\right)$ receptor-mediated contraction. Statistical analyses are shown for the $E_{\max }$ values where ${ }^{*} P<0.05$ and ${ }^{* * *} P<0.001$

compared with vehicle. $E_{\max }$ values and $p E C_{50}$ values for respective concentration-response curves are presented in Table 1. the smooth muscle cell layers except for two compressed areas from the wires in the in vitro pharmacology experiments (Figure 2). Therefore, these areas were not used for any kind of evaluation or analysis in the immunohistochemical experiments.

\section{Expression of G-protein coupled receptors}

Protein expression of individual receptors was evaluated with immunofluorescence using antibodies against the 5- $\mathrm{HT}_{1 \mathrm{~B}}, \mathrm{AT}_{1}$ (Figure 3A, B), $\mathrm{AT}_{2}, \mathrm{ET}_{\mathrm{A}}$ (Figure 3C), and $\mathrm{ET}_{\mathrm{B}}$ receptors. In addition, double immunostaining was performed with $5-\mathrm{HT}_{1 \mathrm{~B}}, \mathrm{AT}_{1}$, and $\mathrm{ET}_{\mathrm{B}}$ receptors together with actin (smooth muscle cell layer) to determine the localization of the receptors. Double staining revealed that all three receptors were found in the smooth muscle cell layer $\left(\mathrm{AT}_{1}\right.$, Figure $\left.3 \mathrm{~A}\right)$.

Fluorescence intensity measurements were performed on all receptor stainings. Because of inter-individual differences and differences in pre-treatment and in vessel size, we did not see a close correlation between immunostaining and the in vitro experiments. However, a marked increase in $\mathrm{AT}_{1}$ receptor immunofluorescence was observed in organ cultured vessels treated with vehicle compared with fresh, non-cultured vessels. The immunofluorescence was reduced in vessels treated with SB-590885, and to a smaller extent after treatment with SB-386023 (Figure 3B), compared with vehicle. No significant differences in 5- $\mathrm{HT}_{1 \mathrm{~B}}, \mathrm{AT}_{2}, \mathrm{ET}_{\mathrm{B}}$, and $\mathrm{ET}_{\mathrm{A}}$ (Figure $3 \mathrm{C}$ ) receptor immunoreactivity were detected.

\section{Expression of phosphorylated B-Raf}

The protein expression of activated p-B-Raf was evaluated with immunofluorescence. As in the receptor immunofluorescence experiments, inter-individual and segmental differences were observed. Nevertheless, an increase in p-B-Raf immunoreactivity was observed in cultured brain vessels compared with fresh non-cultured vessels. In addition, immunofluorescence intensity was clearly reduced in vessels treated with SB-590885 or SB386023 (Figure 4).

\section{Discussion}

The present study demonstrates for the first time that upregulation of the contractile receptors $5-\mathrm{HT}_{1 \mathrm{~B}}, \mathrm{AT}_{1}$, and $\mathrm{ET}_{\mathrm{B}}$ in human cerebral arteries is mediated by $\mathrm{B}$ Raf signaling. These receptor subtypes have been characterized in human cerebral arteries in detail in previous studies [15-17]. In human ischemic stroke, we have observed enhanced levels of protein and mRNA of 5$\mathrm{HT}_{1 \mathrm{~B}}, \mathrm{AT}_{1}$, and $\mathrm{ET}_{\mathrm{B}}$ receptors in middle cerebral artery smooth muscle cells [5]. Presently, the co-incubation of 


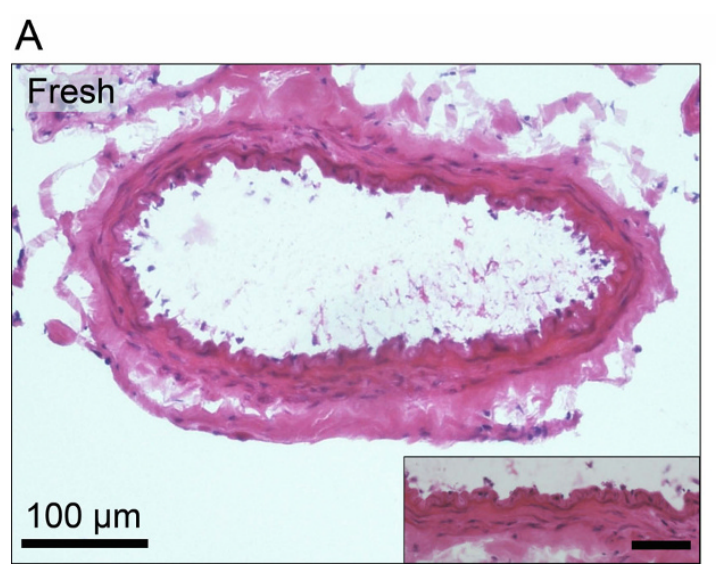

\section{B}

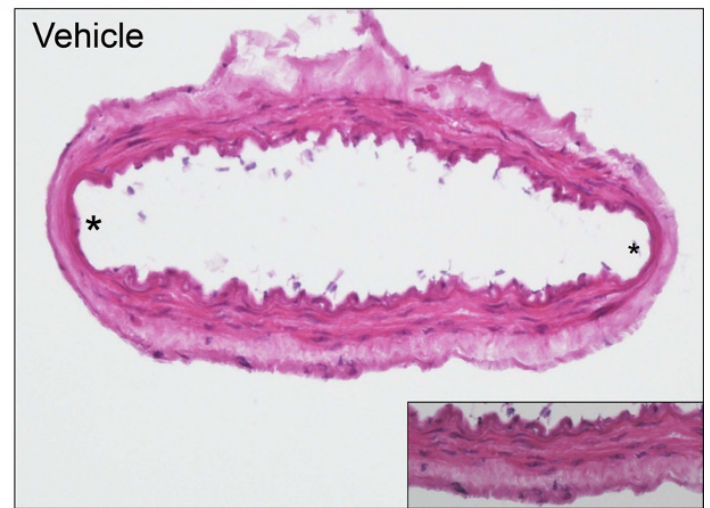

Figure 2 The effect of organ culture and in vitro pharmacology experiments on hematoxylin-eosin staining in human cerebral vessel sections. (A) Fresh, non-cultured vessel; (B) Vehicle-cultured vessel followed by in vitro pharmacology experiment. No morphological changes were observed in the smooth muscle cell layer after the organ culture and in vitro pharmacology experiments compared with the fresh vessel sections. Two compressed areas from the wires during the in vitro pharmacology experiments were observed $\left(^{*}\right)$. These areas were not used for evaluation or analysis. Data were obtained with light microscopy. Insert: higher magnification, scale bar $50 \mu m$.

cerebral arteries with two different B-Raf antagonists prevents organ culture-induced upregulation of contractile responses to 5-CT, Ang II, and ET-1. The effect on receptor-mediated contraction was more prominent after treatment with SB-590885, which is to be expected because it has a lower $K_{d}$ value, and therefore a higher affinity for its ligand, than SB-380623 [12,13].

\section{In vitro pharmacology}

The maximum contraction elicited by $5-\mathrm{CT}$ was significantly reduced, as demonstrated by the reduction in $\mathrm{E}_{\max }$ after co-incubation with SB-590885 (Figure 1A, Table 1). The receptor responsible for this contraction has been demonstrated to be the $5-\mathrm{HT}_{1 \mathrm{~B}}$ receptor subtype, which is also selectively expressed in human cerebral arteries, as demonstrated by protein $5-\mathrm{HT}_{1 \mathrm{~B}}$ expression and inhibition by a selective $5-\mathrm{HT}_{1 \mathrm{~B}}$ antagonist [17-19]. The role of 5-HT and its receptors in ischemia are not clear; while some studies report a protective role for 5-HT receptor agonists [20], others show increased contractility and improvement with $5-\mathrm{HT}$ receptor antagonists [21]. Guilbert et al. show that 5$\mathrm{HT}_{1 \mathrm{~B}}$ is responsible for the 5 -HT aggravation seen in exercise-induced cardiac ischemia in dogs [21]. Additionally, $5-\mathrm{HT}_{1 \mathrm{~B}}$ receptors have been suggested to interact with 20-hydroxyeiscosatetraenoic acid (20-HETE) and thereby contribute to the acute fall in regional cerebral blood flow after SAH [22]. We have previously reported on increased $5-\mathrm{HT}_{1 \mathrm{~B}}$ protein expression and receptor-mediated contraction after $\mathrm{SAH}$ and organ culture in cerebral arteries [14,23], which could impair the cerebral blood flow and thereby contribute to ischemic damage. The present study demonstrates that the selective B-Raf inhibitor SB-590885 significantly decreases 5-
$\mathrm{HT}_{1 \mathrm{~B}}$ receptor-mediated vasoconstriction, suggesting that the elevated contractile response of $5-\mathrm{HT}_{1 \mathrm{~B}}$ receptors observed after organ culture is regulated by the BRaf/MEK/ERK pathway.

Organ culture of isolated human arteries in the presence of SB-590885 or SB-386023 reduced Ang IImediated contraction $(\mathrm{P}<0.001$ for SB-590885 treated vessels, Figure 1B, Table 1). Available data show that cerebral vasoconstriction in response to Ang II is mediated by $\mathrm{AT}_{1}$ receptors, while vasodilatation is mediated by $\mathrm{AT}_{2}$ receptors [24]. The smooth muscle cell $\mathrm{AT}_{1}$ receptors are upregulated and show enhanced contractile responses after experimental cerebral ischemia [25] or in human ischemic stroke [5]. In support, the reduced vasoconstrictor responses observed in the present study after treatment with the B-Raf inhibitor SB-590885 lead to a concomitant reduction of the $\mathrm{AT}_{1}$ receptor protein when examined immunohistochemically. The receptor identity has been confirmed using selective antagonists for the $\mathrm{AT}_{2}$ receptor in human brain vessels [15]. Blockade of the $\mathrm{AT}_{1}$ receptor has been shown to improve injury after transient cerebral ischemia $[26,27]$ and to reduce cardiovascular morbidity and mortality in stroke patients [28].

In agreement with a previous study, the selective $\mathrm{ET}_{\mathrm{B}}$ receptor agonist sarafotoxin 6c (S6c) did not elicit any vasoconstrictor responses in cultured human cerebral arteries [16]. Therefore, the high-affinity phase of the ET-1 biphasic concentration-response curve, corresponding to $\mathrm{ET}_{\mathrm{B}}$ receptor-mediated contraction, was studied. The same situation was seen in the rat middle cerebral artery after experimental SAH, detailed pharmacological analysis revealed participation of the $\mathrm{ET}_{\mathrm{B}}$ receptor [29]. In the present study, we demonstrate a 

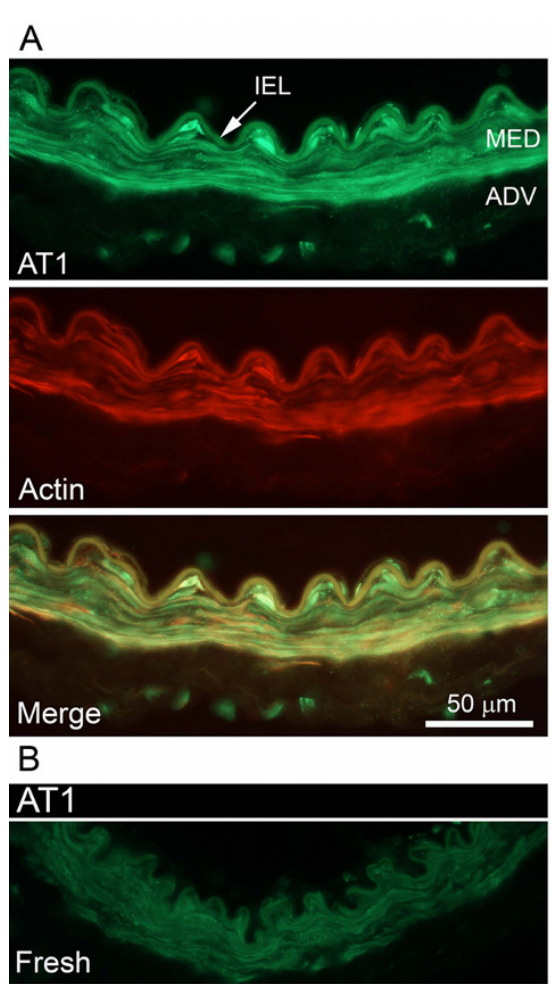

C
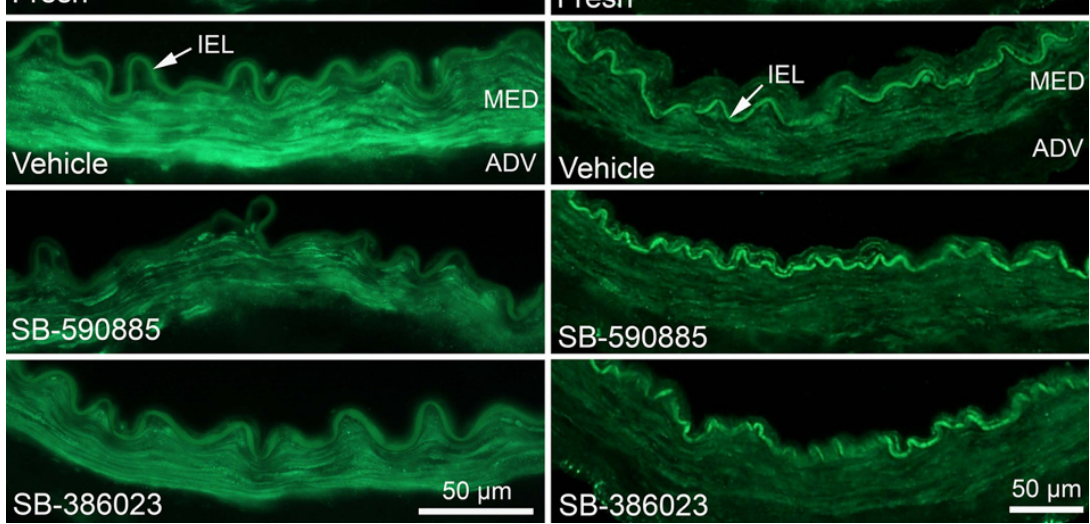

Figure 3 Human cerebrovascular receptor expression. (A) Double staining with actin shows expression of angiotensin $\|$ type 1 (AT $)$ receptors in the medial layer. (B) AT 1 receptor expression in fresh and in cultured vessel segments in the presence of vehicle, SB-590885, or SB386023. The increase in $A T_{1}$ receptor immunoreactivity after culture was diminished significantly after treatment with SB-590885, and diminished slightly after treatment with SB-386023. (C) No difference in endothelin type A (ETA) receptor expression was observed. Autofluorescence was observed in internal elastic lamina. Data were obtained with epifluorescence microscopy. MED - medial layer, ADV - adventitial layer, and IEL internal elastic lamina.

significant reduction of the $\mathrm{ET}_{\mathrm{B}}$ maximum contraction after co-incubation with SB-590885; SB-386023 had a weaker effect (Figure 1C, Table 1). No effect on the $\mathrm{ET}_{\mathrm{A}}$ receptor-mediated contraction was observed after treatment with B-Raf inhibitors. It is well known that cerebral vessels have contractile $\mathrm{ET}_{\mathrm{A}}$ receptors in the smooth muscle cells and relaxant $\mathrm{ET}_{\mathrm{B}}$ receptors in the endothelium. However, there is a phenotypic change after stroke in both animals and humans, with the appearance of contractile $\mathrm{ET}_{\mathrm{B}}$ receptors in the smooth muscle cells $[5,30]$. The effect of selective $\mathrm{ET}_{\mathrm{A}}$ blockers on infarct volume after experimental stroke is ambiguous, with studies showing both effect and no effect [2]. Results have been similar for the combined $\mathrm{ET}_{\mathrm{A}}$ and $\mathrm{ET}_{\mathrm{B}}$ antagonists bosentan and clazosentan. One study using an $\mathrm{ET}_{\mathrm{B}}$ blocker showed an increase in infarct volume [31]. The administration of an $\mathrm{ET}_{\mathrm{B}}$ blocker in conjunction with cerebral ischemia causes a blockade of $\mathrm{ET}_{\mathrm{B}}$ receptor-mediated dilation, which exacerbates the initial vasoconstriction and increases the infarct. The $\mathrm{ET}_{\mathrm{B}}$ blocker might be beneficial if it is administered after upregulation of the $\mathrm{ET}_{\mathrm{B}}$ receptor. 


\section{B-Raf}
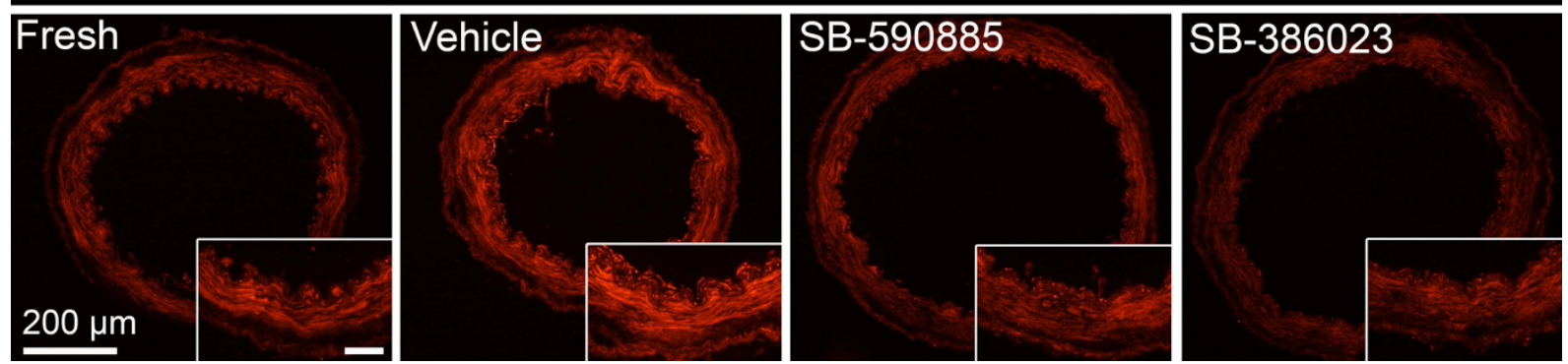

Figure 4 Phosphorylated B-Raf (p-B-Raf) expression in human cerebral vessels. Cultured vessel with vehicle only shows increased immunoreactivity compared with fresh, non-cultured vessel. This effect was markedly reduced after treatment with SB-590885 and SB-386023. Data were obtained with epifluorescence microscopy. Insert: higher magnification, scale bar $50 \mu \mathrm{m}$.

ET receptor antagonists are not the best approach for improving cerebral perfusion after ischemia because of the opposing effects of a strong contractile $\mathrm{ET}_{\mathrm{A}}$ receptor and a dilatory $\mathrm{ET}_{\mathrm{B}}$ receptor. However, a different approach, whereby the signal transduction of the Raf/ MEK/ERK pathway was blocked with the MEK1/2 inhibitor $\mathrm{U} 0126$, diminished the upregulated $\mathrm{ET}_{\mathrm{B}}$ receptormediated contraction and reduced stroke volume [7]. Organ culture of rodent and human cerebral arteries is a way to simulate $\mathrm{ET}_{\mathrm{B}}$ receptor upregulation and to study the molecular mechanisms involved. In the present study, we show that blockade of the MEK/ERK1/2 pathway using upstream B-Raf inhibitors results in attenuated $\mathrm{ET}_{\mathrm{B}}$ receptor-mediated contraction after organ culture.

\section{Immunohistochemistry}

When examined with hematoxylin-eosin staining, no morphological changes were observed in the vessels except for the regions where the steel wires used in the in vitro pharmacology experiments have been attached (Figure 2). However, it became obvious in the immunohistochemical examination that the vessels showed considerable inter-individual differences, most likely due to differences between the patients themselves. Some of the patients exhibited more consistent results than others (e.g., repeated immunostainings displayed stable results). These inter-individual differences could explain the inconsistency in the results obtained with the fluorescence intensity measurements.

Immunohistochemical staining using the $5-\mathrm{HT}_{1 \mathrm{~B}}$ antibody showed no differences between the groups. In other studies, $5-\mathrm{HT}_{1 \mathrm{~B}}$ expression in rat cerebral arteries is increased after middle cerebral artery occlusion and SAH $[3,4]$.

$\mathrm{AT}_{1}$ receptor immunoreactivity was reduced after treatment with SB-590885. Previously, increased $\mathrm{AT}_{1}$ receptor immunofluorescence after $\mathrm{SAH}$ in rats has been shown to be reduced after application of SB386023 [32]. In our study, we observed a decrease in $\mathrm{AT}_{1}$ receptor immunofluorescence intensity after application of SB-590885, but only a small decrease after SB-386023 (Figure 3B), results that are in accordance with the in vitro pharmacology experiments.

$\mathrm{ET}_{\mathrm{A}}$ receptor-mediated contractile responses were not significantly altered by the two B-Raf inhibitors used in the present study (Figure $1 \mathrm{C}$ ). Immunohistochemical examination disclosed the same pattern; no differences were observed between the groups (Figure 3C).

There was an increase in $\mathrm{p}-\mathrm{B}$-Raf immunoreactivity after organ culture and this effect could be reduced considerably in the presence of SB-590885 and SB-380623 (Figure 4). Therefore, the activation of B-Raf protein kinase could be blocked by the application of specific antagonists. We suggest that B-Raf is important for the phenotypic changes of GPCRs observed in the smooth muscle cells of cerebral arteries after organ culture and cerebral ischemia [2]. An interesting question is whether $\mathrm{B}$-Raf functions alone or in a heterodimer in this aspect. There is evidence for B-Raf/C-Raf heterodimerization with highly increased kinase activity compared with the respective homodimers or monomers [33]. Further studies are needed to elucidate whether heterodimerization is important for the regulation of GPCRs in vascular smooth muscle cells after ischemia and organ culture.

\section{Conclusions}

In conclusion, we show that selective inhibition of B-Raf using SB-590885 significantly attenuates 5- $\mathrm{HT}_{1 \mathrm{~B}}, \mathrm{AT}_{1}$, and $\mathrm{ET}_{\mathrm{B}}$ receptor-mediated contraction in human cerebral arteries. Therefore, we suggest that B-Raf is important for the altered GPCR expression observed after cerebral ischemia, and that specific blockage might be a novel approach to reduce tissue damage after stroke.

\section{Methods}

Ethics

This study was approved by the Regional Ethical Review Board in Lund, Sweden (LU-818-01) and has been performed in accordance with the Declaration of Helsinki. 


\section{Tissue collection}

Cerebral arteries were obtained from patients undergoing neurological surgery for removal of brain tumor or seizure-producing cortex in severe cases of epilepsy ( $n=7$, 55 to 77 years old, 4 men and 3 women). Adjacent tissue that was removed contained one or two vessel segments that were used for the experiments. The vessels were dissected during surgery and immediately immersed in cold, sterile Dulbecco's modified Eagle's medium (DMEM, Gibco, Invitrogen, Carlsbad, CA, USA) and transported to the laboratory. The arteries were dissected free from adhering tissue and cut into cylindrical segments approximately $2 \mathrm{~mm}$ in length. The outer diameter of the vessels ranged from 250 to $950 \mu \mathrm{m}$.

\section{Organ culture}

Arterial segments were cultured for $48 \mathrm{~h}$ at $37^{\circ} \mathrm{C}$ in humidified $5 \% \mathrm{CO}_{2}$ and air in serum-free DMEM supplemented with penicillin $(100 \mathrm{U} / \mathrm{ml})$, streptomycin $(100 \mu \mathrm{g} / \mathrm{ml})$, and amphotericin B $(0.25 \mu \mathrm{g} / \mathrm{ml})$ (Gibco). The method of blood vessel culture and upregulation of contractile receptors has been described previously [34]; the upregulation is not altered with serum present in the medium or by incubation in buffer only, but is a metabolically active process. The segments were cultured in well plates, one segment per well, in the absence or presence of B-Raf inhibitors: SB386023, $1 \mu \mathrm{M}$ ( $\mathrm{K}_{\mathrm{d}}$ B-Raf: 2.4 nM, GlaxoSmithKline, UK); SB-590885, $1 \mu \mathrm{M}$, ( $\mathrm{K}_{\mathrm{d}}$ B-Raf: $0.3 \mathrm{nM}$, GlaxoSmithKline); or the same volume of vehicle (dimethyl sulfoxide). Incubation was also performed with $10 \mu \mathrm{M}$ SB-590885, which resulted in non-viable arteries when examined by in vitro pharmacology; therefore arteries incubated in SB-590855 were not used for further experiments. After $24 \mathrm{~h}$ of culture, the DMEM was replaced with new fresh medium and inhibitors or vehicle were added as described above. For each patient and group, one to three vessel segments were incubated and examined by in vitro pharmacology and/or immunohistochemistry (see below).

\section{In vitro pharmacology}

For contractile experiments, a myograph was used to record the isometric tension in isolated cerebral arteries $[35,36]$. The cylindrical segments were threaded on two parallel stainless steel wires (diameter, $40 \mu \mathrm{m}$ ) and mounted in a Mulvany-Halpern myograph (Danish Myo Technology A/S, Aarhus, Denmark). One wire was connected to a force displacement transducer attached to an analogue-digital converter unit (ADInstruments, Chalgrove, UK). The other wire was connected to a micrometer screw, allowing adjustments of the distance between the wires and therefore the vascular tone. Measurements were recorded on a computer by use of a Power Lab unit (ADInstruments). The vessel segments were immersed in temperature-controlled tissue baths $\left(37^{\circ} \mathrm{C}\right)$ containing a bicarbonate buffer solution of the following composition (mM): $\mathrm{NaCl} 119, \mathrm{NaHCO}_{3} 15$, $\mathrm{KCl} 4.6, \mathrm{MgCl}_{2} 1.2, \mathrm{NaH}_{2} \mathrm{PO}_{4} 1.2, \mathrm{CaCl}_{2} 1.5$, and glucose 5.6. The buffer was continuously aerated with oxygen enriched with $5 \% \mathrm{CO}_{2}$, resulting in $\mathrm{pH}$ 7.4. After an equilibration period of $\sim 20 \mathrm{~min}$, each vessel segment was stretched to $90 \%$ of the normal internal circumference, which would be the size each vessel would have if relaxed and under a transmural pressure of $100 \mathrm{~mm} \mathrm{Hg}$ [36]. The normalization procedure makes certain that all vessel segments are set to a normalized internal circumference giving maximal response. Subsequently, the vessels were allowed to stabilize for 20-30 min. The contractile capacity of the vessels was determined by exposure to an isotonic solution containing $63.5 \mathrm{mM} \mathrm{K}$ ${ }^{+}$, obtained by partial change of $\mathrm{NaCl}$ for $\mathrm{KCl}$ in the above buffer. The contraction induced by $\mathrm{K}^{+}$was used as reference for contractile capacity [35].

Concentration-response curves were obtained by cumulative application of $5-\mathrm{CT}\left(5-\mathrm{HT}_{1 \mathrm{~B}}\right.$ receptor agonist, concentration range $10^{-11}$ to $3 \cdot 10^{-5} \mathrm{M}$, Sigma, St. Louis, USA), Ang II ( $\mathrm{AT}_{1}$ and $\mathrm{AT}_{2}$ receptor agonist, concentration range $10^{-12}$ to $10^{-6} \mathrm{M}$, Sigma) and ET-1 $\left(\mathrm{ET}_{\mathrm{A}}\right.$ and $\mathrm{ET}_{\mathrm{B}}$ receptor agonist, concentration range $10^{-}$ ${ }^{14}$ to $3 \cdot 10^{-7} \mathrm{M}$, Alexis Biochemicals, Farmingdale, NY, USA). The contractile responses to $\mathrm{S} 6 \mathrm{c}$, a selective $\mathrm{ET}_{\mathrm{B}}$ receptor agonist, were tested in a few samples and no contractile responses were observed, in agreement with a previous study [16]. Therefore, the high-affinity phase of the ET-1 concentration-response curve was used to study $\mathrm{ET}_{\mathrm{B}}$ receptor-mediated contraction.

\section{Immunohistochemistry}

Immediately after the in vitro pharmacology experiments, the arterial segments were carefully dismantled $(\mathrm{n}=4)$ and embedded in Tissue TEK (Gibco), frozen on dry ice, and kept at $-80^{\circ} \mathrm{C}$ until cryosectioning $(10 \mu \mathrm{m})$. Additionally, both fresh (non-cultured) and cultured arterial segments (described above) were directly embedded in Tissue TEK without prior in vitro pharmacology experiments $(n=3)$. These arterial segments were used for the $\mathrm{ET}_{\mathrm{A}}$ and $\mathrm{ET}_{\mathrm{B}}$ immunohistochemistry experiments because of the irreversible binding of ET-1 to receptors in the in vitro pharmacology experiments that would likely affect antibody-antigen binding [37].

The sections were collected onto Superfrost(r)Plus (Menzel-Gläser, Braunschweig, Germany) glass slides and stored at $-80^{\circ} \mathrm{C}$ until immunohistochemistry. Sections from the in vitro pharmacology experiments were stained with hematoxylin-eosin to evaluate vessel morphology and the possible effects of the in vitro pharmacology experiments. Thawed sections were fixed for 10 minutes in $-20^{\circ} \mathrm{C}$ acetone and rehydrated in phosphate buffered saline (PBS, pH 7.2) containing 0.25\% Triton X- 
100 (PBST) for $3 \times 5 \mathrm{~min}$ at room temperature. The sections were then blocked for $1 \mathrm{~h}$ at room temperature in blocking solution containing PBS and 5\% normal serum (goat or donkey serum, depending on the secondary antibody hosts) to ensure secondary antibody specificity. Subsequently, sections were incubated overnight at $4^{\circ} \mathrm{C}$ with primary antibodies (Santa Cruz Biotechnology, Santa Cruz, CA, USA): goat anti-human $5-\mathrm{HT}_{1 \mathrm{~B}} 1: 100$, rabbit anti-human $\mathrm{AT}_{1}$ 1:100, rabbit anti-human $\mathrm{AT}_{2}$ 1:100, goat anti-human $\mathrm{ET}_{\mathrm{B}}$ 1:150, and rabbit anti-human $\mathrm{ET}_{\mathrm{A}}$ 1:50, diluted in PBST containing 1\% bovine serum albumin (BSA) and 3\% normal serum. Following primary antibody incubation, sections were rinsed in PBS for $2 \times 15$ min and incubated for $1 \mathrm{~h}$ at room temperature with secondary antibodies (FITC-conjugated goat anti-rabbit (Cayman Chemical Co., Ann Arbor, MI, USA) 1:100 or Cy2-conjugated donkey anti-goat (Jackson ImmunoResearch, West Grove, PA, USA) 1:200) in PBST containing 1\% BSA and $3 \%$ normal serum (goat and donkey serum, respectively). Sections were then rinsed in PBS for $2 \times 15 \mathrm{~min}$ and mounted in anti-fading mounting medium (Vectashield; Vector Laboratories Inc., Burlingame, CA, USA) or polyvinyl alcohol mounting medium (compatible with Cy2-conjugated secondary antibodies, Sigma). The procedure was repeated on three different occasions to ensure reproducibility. The same experimental procedure was used for negative controls, but primary antibodies were omitted, resulting in no staining in the tissue except for auto-fluorescence in the internal elastic lamina.

Double immunostaining was performed for the 5$\mathrm{HT}_{1 \mathrm{~B}}, \mathrm{AT}_{1}$, and $\mathrm{ET}_{\mathrm{B}}$ receptors. Antisera against the receptors (described above) were used along with mouse anti-human smooth muscle actin 1:200 (Santa Cruz Biotechnology) and Texas Red-conjugated donkey antimouse 1:200 (Jackson ImmunoResearch).

In addition, immunostaining against p-B-Raf was performed on the sections. The protocol mentioned above was used with a primary rabbit anti-human phosphospecific B-Raf antibody 1:25 (Abcam, Cambridge, UK). The secondary antibody used was Cy3-conjugated donkey anti-rabbit 1:400 (Jackson ImmunoResearch).

Immunoreactivity was visualized at the appropriate wavelengths with a light and epifluorescence microscope (Nikon 80i; Tokyo, Japan) and photographed with an attached Nikon DS-2Mv camera. To evaluate colocalization, images from double immunostaining were superimposed in Adobe Photoshop CS (Adobe systems, Mountain View, CA, USA).

\section{Analysis and statistics}

Contractile responses from the in vitro pharmacology experiments are expressed as percentage of the contraction induced by $63.5 \mathrm{mM} \mathrm{K}^{+}$. The $\mathrm{E}_{\max }$ value represents the maximum contractile response elicited by an agonist and the pEC50 represents the negative logarithm of the drug concentration that elicited half the maximum response. For biphasic responses, $\mathrm{E}_{\max (1)}$ and $\mathrm{pEC}_{50}$ (1) describe the high-affinity phase, and $\mathrm{E}_{\max (2)}$ and $\mathrm{pEC}_{50}$ (2) describe the low-affinity phase.

The protein expression of the $5-\mathrm{HT}_{1 \mathrm{~B}}, \mathrm{AT}_{1}, \mathrm{AT}_{2}, \mathrm{ET}_{\mathrm{B}}$, and $\mathrm{ET}_{\mathrm{A}}$ receptors in the smooth muscle cell layer of each vessel were analyzed by fluorescence intensity measurements in four areas within each vessel sample ( $n=3$ to 4 patients in each group) by use of the ImageJ software http://rsb.info. nih.gov/ij. The four areas were chosen after evaluating the hematoxylin/eosin staining results of all specimens.

Data are expressed as mean \pm standard error of the mean (s.e.m.), and $n$ refers to the number of patients. Statistical analyses were performed with Kruskal-Wallis non-parametric test followed by Dunn's multiple comparison test, where $\mathrm{P}<0.05$ was considered significant.

\section{Study limitations}

Human tissue was obtained during neurosurgery for treatment of tumors or epilepsy. Although the surgeons carefully dissected out adjacent non-cancerous or seizure-producing tissue, effects on adjacent tissue cannot be excluded. The collection of human cerebral arteries is performed over a long period of time. Finally, there was great variation in vessel diameter, owing to limited access to human material.

\section{List of abbreviations}

5-CT: 5-carboxamidotryptamine; 5-HT 1B: 5-hydroxytryptamine type 1 B; Ang II: Angiotensin II; $\mathrm{AT}_{1}$ : Angiotensin II type 1; ERK1/2: Extracellular signalregulated kinase 1 and 2; ET-1: Endothelin-1; $E T_{B}$ : Endothelin type $B ;$ GPCR: G-protein coupled receptor; MEK: Mitogen-activated ERK activating kinase

\section{Acknowledgements}

Thanks to Karin Warfvinge and Warfvinge Science Support AB http://www. sciencesupport.se/ for assistance and valuable comments on the manuscript. This work was supported by the Swedish Research Council, the Heart and Lung Foundation, Sweden, and the Lundbeck Foundation, Denmark.

\section{Author details}

'Division of Experimental Vascular Research, Department of Clinical Sciences, Lund University, Lund, Sweden. ²Department of Neurosurgery, Lund University Hospital, Lund, Sweden.

\section{Authors' contributions}

HA participated in the design of the study, performed the experiments, analyzed the data, and wrote the manuscript. HS and ON performed the surgeries and reviewed the manuscript. LE conceived the study, guided the experimental procedures, and participated in writing the manuscript.

\section{Competing interests}

The authors declare that they have no competing interests.

Received: 25 August 2010 Accepted: 11 January 2011 Published: 11 January 2011

\section{References}

1. O'Collins VE, Macleod MR, Donnan GA, Horky LL, van der Worp BH, Howells DW: 1,026 experimental treatments in acute stroke. Ann Neurol 2006, 59(3):467-477. 
2. Edvinsson L: Cerebrovascular endothelin receptor upregulation in cerebral ischemia. Curr Vasc Pharmacol 2009, 7(1):26-33.

3. Ansar S, Vikman P, Nielsen M, Edvinsson L: Cerebrovascular ETB, 5-HT1B, and $\mathrm{AT} 1$ receptor upregulation correlates with reduction in regional $\mathrm{CBF}$ after subarachnoid hemorrhage. Am J Physiol Heart Circ Physiol 2007, 293(6):H3750-3758.

4. Maddahi A, Edvinsson L: Enhanced expressions of microvascular smooth muscle receptors after focal cerebral ischemia occur via the MAPK MEK/ ERK pathway. BMC Neurosci 2008, 9:85.

5. Vikman P, Edvinsson L: Gene expression profiling in the human middle cerebral artery after cerebral ischemia. Eur J Neurol 2006, 13(12):1324-1332.

6. Ansar S, Edvinsson L: Subtype activation and interaction of protein kinase $\mathrm{C}$ and mitogen-activated protein kinase controlling receptor expression in cerebral arteries and microvessels after subarachnoid hemorrhage. Stroke 2008, 39(1):185-190.

7. Henriksson M, Stenman E, Vikman P, Edvinsson L: MEK1/2 inhibition attenuates vascular ETA and ETB receptor alterations after cerebral ischaemia. Exp Brain Res 2007, 178(4):470-476.

8. Henriksson M, Stenman E, Edvinsson L: Intracellular pathways involved in upregulation of vascular endothelin type B receptors in cerebral arteries of the rat. Stroke 2003, 34(6):1479-1483.

9. O'Neill E, Kolch W: Conferring specificity on the ubiquitous Raf/MEK signalling pathway. Br J Cancer 2004, 90(2):283-288.

10. Marais R, Light $Y$, Paterson HF, Mason CS, Marshall CJ: Differential regulation of Raf-1, A-Raf, and B-Raf by oncogenic ras and tyrosine kinases. J Biol Chem 1997, 272(7):4378-4383.

11. Papin C, Denouel-Galy A, Laugier D, Calothy G, Eychene A: Modulation of kinase activity and oncogenic properties by alternative splicing reveals a novel regulatory mechanism for B-Raf. J Biol Chem 1998, 273(38):24939-24947.

12. Hughes JP, Staton PC, Wilkinson MG, Strijbos PJ, Skaper SD, Arthur JS, Reith AD: Mitogen and stress response kinase-1 (MSK1) mediates excitotoxic induced death of hippocampal neurones. J Neurochem 2003, 86(1):25-32.

13. Takle AK, Brown MJ, Davies S, Dean DK, Francis G, Gaiba A, Hird AW, King FD, Lovell PJ, Naylor A, et al: The identification of potent and selective imidazole-based inhibitors of B-Raf kinase. Bioorg Med Chem Lett 2006, 16(2):378-381.

14. Hansen-Schwartz J, Hoel NL, Xu CB, Svendgaard NA, Edvinsson L: Subarachnoid hemorrhage-induced upregulation of the 5-HT1B receptor in cerebral arteries in rats. J Neurosurg 2003, 99(1):115-120.

15. Ansar S, Nilsson E, Nilsson O, Säveland H, Edvinsson L: MAPK signalling pathway regulate cerebrovascular receptor expression in human cerebral arteries. J Cereb Blood Flow Metab 2009, 29:5495-S496, (Abstract).

16. Nilsson T, Cantera L, Adner M, Edvinsson L: Presence of contractile endothelin-A and dilatory endothelin-B receptors in human cerebral arteries. Neurosurgery 1997, 40(2):346-351, discussion 351-343.

17. Nilsson T, Longmore J, Shaw D, Olesen IJ, Edvinsson L: Contractile 5-HT1B receptors in human cerebral arteries: pharmacological characterization and localization with immunocytochemistry. Br J Pharmacol 1999, 128(6):1133-1140.

18. Longmore J, Shaw D, Smith D, Hopkins R, McAllister G, Pickard JD, Sirinathsinghiji DJ, Butler AJ, Hill RG: Differential distribution of 5HT1D- and 5HT1B-immunoreactivity within the human trigemino-cerebrovascular system: implications for the discovery of new antimigraine drugs. Cephalalgia 1997, 17(8):833-842.

19. Razzaque Z, Heald MA, Pickard JD, Maskell L, Beer MS, Hill RG, Longmore J: Vasoconstriction in human isolated middle meningeal arteries: determining the contribution of 5-HT1B- and 5-HT1F-receptor activation. Br J Clin Pharmacol 1999, 47(1):75-82.

20. Prehn JH, Welsch M, Backhauss C, Nuglisch J, Ausmeier F, Karkoutly C, Krieglstein J: Effects of serotonergic drugs in experimental brain ischemia: evidence for a protective role of serotonin in cerebral ischemia. Brain Res 1993, 630(1-2):10-20.

21. Guilbert F, Lainee P, Dubreuil B, McCort G, O'Connor SE, Janiak P, Herbert JM: Serotonin aggravates exercise-induced cardiac ischemia in the dog: effect of serotonin receptor antagonists. Eur J Pharmacol 2004, 497(1):55-63.

22. Cambj-Sapunar L, Yu M, Harder DR, Roman RJ: Contribution of 5hydroxytryptamine1B receptors and 20-hydroxyeiscosatetraenoic acid to fall in cerebral blood flow after subarachnoid hemorrhage. Stroke 2003, 34(5):1269-1275

23. Hoel NL, Hansen-Schwartz J, Edvinsson L: Selective up-regulation of 5-HT (1B/1D) receptors during organ culture of cerebral arteries. Neuroreport 2001, 12(8):1605-1608.

24. Vincent JM, Kwan YW, Chan SL, Perrin-Sarrado C, Atkinson J, Chillon JM: Constrictor and dilator effects of angiotensin II on cerebral arterioles. Stroke 2005, 36(12):2691-2695.

25. Stenman $E$, Edvinsson $\mathrm{L}$ : Cerebral ischemia enhances vascular angiotensin AT1 receptor-mediated contraction in rats. Stroke 2004, 35(4):970-974.

26. Hosomi N, Nishiyama A, Ban CR, Naya T, Takahashi T, Kohno M, Koziol JA: Angiotensin type 1 receptor blockage improves ischemic injury following transient focal cerebral ischemia. Neuroscience 2005, 134(1):225-231.

27. Engelhorn T, Goerike S, Doerfler A, Okorn C, Forsting M, Heusch G, Schulz R: The angiotensin II type 1-receptor blocker candesartan increases cerebral blood flow, reduces infarct size, and improves neurologic outcome after transient cerebral ischemia in rats. J Cereb Blood Flow Metab 2004, 24(4):467-474.

28. Schrader J, Luders S, Kulschewski A, Berger J, Zidek W, Treib J, Einhaupl K, Diener HC, Dominiak P: The ACCESS Study: evaluation of Acute Candesartan Cilexetil Therapy in Stroke Survivors. Stroke 2003, 34(7):1699-1703.

29. Hansen-Schwartz J, Hoel NL, Zhou M, Xu CB, Svendgaard NA, Edvinsson L: Subarachnoid hemorrhage enhances endothelin receptor expression and function in rat cerebral arteries. Neurosurgery 2003, 52(5):1188-1194, 1194-1185.

30. Stenman E, Malmsjo M, Uddman E, Gido G, Wieloch T, Edvinsson L: Cerebral ischemia upregulates vascular endothelin $\mathrm{ET}(\mathrm{B})$ receptors in rat. Stroke 2002, 33(9):2311-2316.

31. Chuquet J, Benchenane K, Toutain J, Mackenzie ET, Roussel S, Touzani O: Selective blockade of endothelin-B receptors exacerbates ischemic brain damage in the rat. Stroke 2002, 33(12):3019-3025.

32. Ansar S: Protein kinase inhibition in late cerebral ischemia after subarachnoid hemorrhage. Thesis Lund University, Sweden; 2007.

33. Rushworth LK, Hindley AD, O'Neill E, Kolch W: Regulation and role of Raf1/B-Raf heterodimerization. Mol Cell Biol 2006, 26(6):2262-2272.

34. Adner M, Geary GG, Edvinsson L: Appearance of contractile endothelin-B receptors in rat mesenteric arterial segments following organ culture. Acta Physiol Scand 1998, 163(2):121-129.

35. Hogestatt ED, Andersson KE, Edvinsson L: Mechanical properties of rat cerebral arteries as studied by a sensitive device for recording of mechanical activity in isolated small blood vessels. Acta Physiol Scand 1983, 117(1):49-61.

36. Mulvany MJ, Halpern W: Contractile properties of small arterial resistance vessels in spontaneously hypertensive and normotensive rats. Circ Res 1977, 41(1):19-26.

37. Meens MJ, Fazzi GE, van Zandvoort MA, De Mey JG: Calcitonin generelated peptide selectively relaxes contractile responses to endothelin-1 in rat mesenteric resistance arteries. J Pharmacol Exp Ther 2009, 331(1):87-95.

doi:10.1186/1471-2202-12-5

Cite this article as: Ahnstedt et al: Human cerebrovascular contractile receptors are upregulated via a B-Raf/MEK/ERK-sensitive signaling pathway. BMC Neuroscience 2011 12:5. 